Bartłomiej Grysa

Higher School of Toruń

\title{
The Cultural Heritage of the Knanaya Christians
}

\section{Kerala and the West - first contacts}

The Keralites have been in contact with the West from time out of mind. Kerala attracted numerous foreigners with its beauty and unique world of spices - pepper, which was available only in Malabar ${ }^{1}$ up to the $18^{\text {th }}$ century, ginger, cardamom and cinnamon, commonly used by the affluent strata of western Asia. Most trade routes led through the sea. The Keralites established trade relationships with the Assyrians, Babylonians, Egyptians, Phoenicians, Greeks, Jews, Romans and the Chinese. As a result new religious and cultural ideas began to penetrate the early Keralite society. The ancient Egyptians, Assyrians and Babylonians purchased cardamom and cinnamon in Kerala. Oriental scents were used by the Egyptians to embalm bodies after death. It is known that Queen Hatshepsut went from Egypt to the Orient in $1500 \mathrm{BC}$ to purchase perfumes. At that time perfumes were produced only in Kerala.

The Greeks also knew the trade routes leading to India. Megasthenes, the Greek ambassador at the court of Chandragupta Maurya, described the history of this country in his book Indica. Kerala's contacts with Persia could have begun prior to the reign of Cyrus.

The ports situated at the Malabar Coast were of great importance. Many of them, e.g., Muziris, Thindis, Bakary, Nilkindia, Beypur (Ophir) and Kannur (Naura) were known in the ancient times. Ophir, mentioned in the Bible as the place from which gold, ivory and peacocks were brought, is sometimes identified with the port Beypur in the vicinity of Kozhikode (Calicut). Over the centuries the ports were destroyed by various natural disasters. Muziris was described

\footnotetext{
${ }^{1}$ Only in the $18^{\text {th }}$ century the Dutch began cultivating it in Java.
} 
on the Jewish copperplates as Mahodayapattanam, Makodayapattanam and Thiruvanchikulam, and as Muchiri in the Tamil Sangam literature.

\section{The mission of St Thomas the Apostle}

There is a very strong tradition that assigns to St Thomas the Apostle the proclamation of the Gospel in India, in Kerala, starting with Kodungallur (Cranganore, ancient Muziris). According to the tradition, the Apostle gained the first fruits of Christians in this country and erected the first places of worship on the Indian coast and in the high mountain ranges. Then St Thomas moved to Tamil Nadu, where he was to die a martyr's death and was to be buried in Mylapore (nowadays the Southern part of Chennai, formerly Madras). The hill of St Thomas in Chinna Malai in Tamil Nadu has served as a place of pilgrimage for Indian Christians until today.

Another tradition of sowing Christianity in India tells about the Syriac colonization. According to this tradition Christians were deprived of their priests and spiritual leaders for a long period of time after martyrdom of St Thomas the Apostle. The Hindu sage Manikya Vachagar was to reconvert many of them to Hinduism. In fact, the above-mentioned person was a Tamil poet from the $10^{\text {th }}$ century. Those who remained faithful to Christ, despite persecutions, were to wear wooden crosses adorned with threads around their necks.

Some modern historians try to identify the Christian colonization of Kerala with a group of Christians from Persia or Mesopotamia under the leadership of Mar Sapor (Xabro), Mar Paruta (Piruz, Prodh or Aphroth) and Sabrisho in the year 823. Mingana claims that Sapor and Sabrisho were the same person, and that the name Sabrisho (meaning in Syriac "Jesus is my hope") is more correct here.

While the first group of Christians still clang to their traditions and identity - they settled in the vicinity of Cochin (i.e., the Southists) - the later settlers quickly began mixing through marriages with the local people and thus they lose their identity (i.e., the Northists).

\section{Thomas of Cana}

Qnay Thoma, Thomas the merchant, Tangara Thoma from Jerusalem called Quinai, Knai, Chinai or Canai probably came from Armenia, Babylon or Jerusalem, and arrived in Mailapur or Kodungallore or Mahodar (Parure-Patan) in the year 345, 730, 745, 753, 811 or 825 . The Syriac Thomas of Cana arrived in Kodungallore in the year 345, together with Mar Joseph from Edessa, clergy and laity from Jerusalem, Baghdad and Nineveh. With the permission of the ruler of Kerala, Cheraman Perumal, was to come by ship under the flag of the Star 
of David (see more about the Jewish influences among the Knanaya Christians in the next section) in 345 , with a group of ca. 400 people, including a bishop, two priests, several deacons and 72 families ${ }^{2}$ belonging to 7 tribes. ${ }^{3}$ The ruler of Kerala gave them enough land to built houses and a church in Mahodar Patanam. They settled down on the island of Maliankara near Kodungallore. The local Christians accepted them with gratitude, recognizing Bishop Mar Joseph of Edessa and their rite. Since then the Christians of Kerala have been known as Syrian Christians.

Thomas of Cana himself was considered a pilgrim, king, monk-bishop or saint. According to Bishop Roz his name was mentioned in Qurbana among the names of other saints.

\section{Written sources concerning Knanaya Christians' history}

There are preserved copperplates known especially among the Jews of Cochin. They concern the written privileges for Knanaya Christians, which are dated at the earliest to the $7^{\text {th }}$ century. ${ }^{4}$ Today we know them mostly due to the $16^{\text {th }}$ century translations.

The earliest literary sources of the Knanites' history, which are available today, are the logs of Pliny (the $1^{\text {st }}$ century), Periplus (the $1^{\text {st }}$ century), Ptolemy (the $2^{\text {nd }}$ century) and Cosmas Indicopleustes (the $6^{\text {th }}$ century). ${ }^{5}$ They describe the Christian centres in the ports of Muziris, Tyndis, Barace and Nilkindia. Another source is the records of Archbishop John of Monte Corvino, a Latin missionary sent to China, who stopped at Quilon (the $13^{\text {th }}$ century). He reports about a decrease of the number of Christians and Jews in Kerala at that time. The other reports belong to the friar Odoric of Pordenone, the friar Jordanus of Severic and John de Marignolli of Florence (all of them come from the $14^{\text {th }}$ century). Duarte Barbosa (1500-1516) was the first Portuguese official in Malabar. He also wrote about the social, religious and economic life of the Kerala Christians. Finally, Diogo Gonsalves, a Jesuit, reported in his Historia do Malavar (History of Malabar) about the synod in Diamper (Udayamperoor), which became a turning point in the history of St Thomas' Christians.

Songs and local customs, letters, documents and logs are the other sources of knowledge about St Thomas' Christians. For example, they belong to:

\footnotetext{
${ }^{2}$ Symbol of 72 disciples of Christ.

${ }^{3}$ Bagi, Belkuth, Hadi, Kujalig, Koja, Mugmuth, Thegmuth - the symbolism of the Seven Sacraments.

${ }^{4}$ Stephen Neill, A History of Christianity in India. The Beginnings to AD 1707, Cambridge University Press 1984, p. 390.

${ }^{5}$ Joseph Kulathramannil, Cultural Heritage of Knanaya Syrian Christians, St Mary's Knanaya Church, Sharjah 2000, pp. 20-21.
} 
1. Mar Jacob, the Chaldean bishop who arrived in Malabar in 1503. In 1524, the houses and churches of Christians in Cranganore were destroyed by fire in a conflict between Cochin and Calicut (Kozhikode). This fact made the bishop write a letter to the king of Portugal asking him for help for the Malabar Christians. This disaster might have been one of the reasons for the Knanites moving to the south.

2. Mar Abraham, who came to Malabar in 1556. He exposed himself to a local ruler by his Portuguese influences. However, the Knanites were the ones who stood up for him.

3. Antonio da Gouvea, a secretary of Dom Alexis de Menesis, described the arrival of Thomas of Cana from Armenia to Cranganore, granting him privileges recorded on copperplates, history of legitimate and illegitimate children of Thomas of Cana and the distinction between Northern and Southern Christians of St Thomas in the year 1606.

4. Bishop Roz, a missionary among Malabar Christians (1585), who became the Bishop of Angamali. We know his long report written in 1604, in which he gathered written and oral sources both from Christians and non-Christians. He dates the arrival of Thome Cananeno (Thomas of Cana) from Babylonia in Cranganore to the year 346. This document is located in the library of the British Museum. According to Roz in Malabar before the arrival of Thomas of Cana there were St Thomas' Christians who fled from Mailapore because of persecutions. He describes Thomas of Cana as a very influential man who received royal privileges and subsidies from the ruler of Cranganore. The descendants of Thomas of Cana were not to come into marriage with other St Thomas' Christians. His description makes us conclude that there were two lineages of Christians in southern India. The wealthy and respected descendants of Thomas of Cana took care of the others and when they tried to make them slaves there were disagreements and disputes. That is why the Knanaya Christians built separate churches in Kaduthuruthy and Kottayam. He also writes that the name of Thomas of Cana was mentioned in Qurbana among the names of other saints.

5. Diogo do Couto, a Portuguese, who lived in India for 15 years. His book entitled Decadas da Asia is the continuation of the work of João de Barros, edited in 1611. It concerns Thomas of Cana, who was to arrive in Cranganore from Armenia and the privileges written on the copperplates. In his opinion Thomas of Cana did not arrive at the Malabar Coast till 811. It was a group of Armenians with their wives who accompanied him to Cranganore. Their descendants lived in Diampar, Kottayam and Kaduthuruthy. Couto says that Thomas of Cana built three churches in Cranganore and the local Christians regarded him as a saint.

6. Veticutel Cathanar Mathai, a Western Syriac priest from Malabar, according to whom Thomas of Jerusalem came to India with a group of 
believers from Jerusalem, Baghdad and Nineveh. Before he arrived there with the blessing of the Catholicos of the East, he had come to India to recognize the situation of the local Christians. They landed in Malyomkare in 345. The Malabar Christians recognized them and led to the king who gave them many privileges and a large portion of land. ${ }^{6}$ The other authors include:

\begin{tabular}{|c|c|c|c|c|c|}
\hline \multirow[t]{2}{*}{ Date } & \multirow[t]{2}{*}{ Author } & Designation & $\begin{array}{l}\text { Country } \\
\text { of origin }\end{array}$ & $\begin{array}{l}\text { Place of the } \\
\text { arrival }\end{array}$ & $\begin{array}{l}\text { Date } \\
\text { of the } \\
\text { arrival }\end{array}$ \\
\hline & & \multicolumn{4}{|c|}{ of Thomas of Cana } \\
\hline 1516 & $\begin{array}{l}\text { Alvaro Penteado who arrived in India } \\
\text { in } 1510 \text {. In } 1516 \text { he wrote to the king of } \\
\text { Portugal about St Thomas Christians in } \\
\text { Cranganore }\end{array}$ & "Merchant" & Armenia & Cranganore & - \\
\hline 1533 & Abuna & Tome de Canane & Canane & Miliapur & - \\
\hline 1578 & Francisco Dionysio, SJ & Quinai Thome & Babylon & Cranganore & 825 \\
\hline 1579 & Antonio Monserrate, SJ & Quinay-Thoma & "Suriano" & Cranganore & - \\
\hline 1604 & John Campori, SJ & Quinai Thome & Armenia & Cranganore & 344 \\
\hline 1636 & $\begin{array}{l}\text { Paulo da Trinidade, OFM, }(1570-1650) \\
- \text { he spent in India over } 55 \text { years }\end{array}$ & Thome Cana & Armenia & Cranganore & - \\
\hline 1657 & Joseph Maria Sebastiani, OCD & Thome Cana & Armenia & Cranganore & - \\
\hline 1676 & Fr Matthew of St Joseph, OCD ${ }^{1}$ & Chinai Thome & Canaan & Serra & - \\
\hline 1709 & Mar Gabriel & Merchant Thomas & Jerusalem & Malabar & 745 \\
\hline $1720 / 1730$ & Mathai & Tangara Thoma & Jerusalem & Malabar & 345 \\
\hline 1782 & Cariatti & Knai Thoma & Babylon & Malabar & 753 \\
\hline 1869 & Ittoop Reitor & Knai Thoma & Jerusalem & Malabar & 345 \\
\hline 1872 & Kurien Padri & Thomas of Canaan & Syria & Kodungallore & 345 \\
\hline 1887 & W. Logan & Merchant Thomas & Baghdad & Malabar & 745 \\
\hline 1891 & G. M. Rae & Merchant Thomas & Baghdad & Malabar & $745^{2}$ \\
\hline
\end{tabular}

${ }^{1}$ Donald F. Lach and Edwin J. Van Kley, Asia in the Making of Europe, vol. III, University of Chicago 1993, p. 925.

${ }^{2}$ George Appasserry, "Qnai-Thoma and Kaldaya Qurbana," The Harp vol. XXI, SEERI, Kottayam 2006, pp. 266-268.

\section{Who are the Knanites?}

One can distinguish two Knanite communities: the endogamous of Oriental origin (Jewish, Armenian and/or Syriac) and the mixed one. Endogamy among the Knanites is traditionally associated with the conviction that the elders of Edessa sending Thomas of Cana along with a group of bishops, clergy and families advised them not to interfere into marriages with local people so as not to tarnish their holiness and not to accept pagan practices, just as with the Jews. Moreover, the Knanites rely on Genesis 24 where Abraham asks his servant Eliezer not to take a wife for his son among the Canaanites (pagans), but from his native land. The Knanites, who probably received Christianity directly from the Judeo-Christians, hold to this tradition today.

\footnotetext{
${ }^{6}$ Joseph Kulathramannil, Cultural Heritage..., pp. 11-13.
} 
The Knanites can be divided according to their confessional affiliation as follows: ${ }^{7}$

- Jacobite Knanites belonging to the Jacobite Syrian Christian Church in India recognizing the sovereignty of the Syrian-Orthodox Church: ca. 150,000;

- Knanaya Catholics who are part of the Syro-Malabar Church, the Archdiocese of Kottayam: ca. 161,000;

- Knanaya Pentecostals: ca. 50,000;

- others: ca. 10,000.

Total: ca. 371,000 .

St Thomas Christians are said to be "Semitic in prayer, Indian in culture and Christian in religion." ${ }^{8}$ Originally, until the $8^{\text {th }}$ century the predominant cultural factor was Semitic. Only with the arrival of Muslims in Kerala the Knanaya culture turned to Hinduism and Brahmanism in order to obtain protection from the Hindu rulers. The Aryanization of St Thomas Christians, which preceded their Latinization, also made its mark on their culture, which I will try to present, giving the example of the wedding customs.

\section{Relations to the Jewish tradition}

The tradition concerning the mission of St Thomas the Apostle assigns to him conversions of many Jews in Malabar to Christianity. It is not without reason that the cross of St Thomas is called Nasrani Menora and the name Nasrani operates as a Christian. Much evidence testifies that the culture of St Thomas Christians became a unique combination of Jewish, Syriac and Indian traditions.

The name Knanaya derives from the Hebrew kana'im, which is translated as "ones who are zealous, overzealous" or from the names Kenan or Cainan. The biblical tradition, which identifies them with the Kenites, is based among others on the following passages:

On that day the Lord made a covenant with Abram and said, "To your descendants I give this land, from the river of Egypt to the great river, the Euphrates - the land of the Kenites, Kenizzites, Kadmonites"9

Then [Balaam] saw the Kenites and uttered his oracle: "Your dwelling place is secure, your nest is set in a rock." 10

The descendants of Moses' father-in-law, the Kenite, went up from the City of Palms with the men of Judah to live among the people of the Desert of Judah in the Negev near Arad. ${ }^{11}$

\footnotetext{
${ }^{7}$ Data from 2001 and 2006.

${ }^{8}$ Fr Placid J. Podipara, CMI.

${ }^{9}$ Genesis 15:18-19 (New International Version 1984).

${ }^{10}$ Numbers 24:21 (New International Version 1984).

${ }^{11}$ Judges 1:16 (New International Version 1984).
} 
Heber the Kenite had left the other Kenites, the descendants of Hobab, Moses' brother-in-law, and pitched his tent by the great tree in Zaanannim near Kedesh. ${ }^{12}$

Then [Saul] said to the Kenites, "Go away, leave the Amalekites so that I do not destroy you along with them; for you showed kindness to all the Israelites when they came up out of Egypt." So the Kenites moved away from the Amalekites. ${ }^{13}$

Another tradition derives Knanaya from Cainan or Kenan son of Enosh (Enos) son of Seth:

When Enosh had lived 90 years, he became the father of Kenan. ${ }^{14}$

the son of Cainan, the son of Arphaxad, the son of Shem, the son of Noah, the son of Lamech, the son of Methuselah, the son of Enoch, the son of Jared, the son of Mahalalel, the son of Kenan. ${ }^{15}$

The presence of Jews in India has already been certified in the book of Esther (ca. the $2^{\text {nd }}$ century BC):

At once the royal secretaries were summoned - on the twenty-third day of the third month, the month of Sivan. They wrote out all Mordecai's orders to the Jews, and to the satraps, governors and nobles of the 127 provinces stretching from India to Cush. ${ }^{16}$

Probably it was about the Jews who settled in Baluchistan, which was a historic part of India. However, there are no traces of this diaspora today.

In addition, three groups of Jews migrated to India:

1. Bene Israel - in Mumbai, Marathi, Konkan, Maharashtra. Their number was about 20,000 during the period of their greatest abundance. ${ }^{17}$ The first immigration dates back to $722 \mathrm{BC}$ after the Assyrian invasion of Judea, another to $587 \mathrm{BC}$ as a result of the Babylonian captivity and the next to $175 \mathrm{BC}-$ the reign of Antioch Epiphanes, which preceded the rise of the Maccabeans. ${ }^{18}$

2. Jews from Cochin - originally settled in Cranganore and the surrounding area, where they lived to the $15^{\text {th }}$ century when Muslims forced them to immigrate to Cochin. Their number has never exceeded 2,500. When Moses Pereira de Paiva from Amsterdam was sent to the Jews of Cochin in 1685, he reported that 70-80 thousand Jews had emigrated from Majorca to Malabar in 370. They had found grace in the eyes of Cheraman Perumal and their leader had been a man named Joseph Rabban, ${ }^{19}$ who was a Jewish merchant probably originating from Yemen. It is not hard to see here an analogy to the history of Thomas of Cana and his group.

\footnotetext{
${ }^{12}$ Judges 4:11 (New International Version 1984).

${ }^{13} 1$ Samuel 15:6 (New International Version 1984).

${ }^{14}$ Genesis 5:9 (New International Version 1984).

${ }^{15}$ Luke 3:36-37 (New International Version 1984).

${ }^{16}$ Esther 8:9 (New International Version 1984).

${ }^{17}$ I.e., until 1951.

${ }^{18}$ Rachael Rukmini Israel, The Jews of India, Mosaic Books, New Delhi 2001, p. 9.

${ }^{19}$ In Judeo-Malayalam Isuppu Irabban.
} 
3. Baghdadi Jews (from Iraq, Syria, Iran and Afghanistan) - came to India in the $18^{\text {th }}$ century, first of all from Aleppo in Syria. In the $19^{\text {th }}$ century their immigration intensified - from Yemen, Iraq and Iran. As opposed to other groups they never assimilated, preserving their Hebrew and Arabic languages.

The impact of the Jewish colonies on the presence of St Thomas Christians was presented among others in Fr Thomas Puthiankunnel's paper entitled Jewish colonies of India paved the way for St Thomas. For that reason some researchers opt for the Jewish origin of the Knanaya community.

In addition, such customs like Nasrani Hagbah - raising Peshitta after unveiling the veil separating the chancel from the rest of church, circumcision, celebrating Shabbat and Qurbana after it until the Portuguese arrival - show common features with the Ethiopic Christianity coming directly from Judaism.

\section{The rite of marriage}

The rite of marriage among the Knanaya Christians shows an extraordinary wealth of content. In this rite, besides the betrothed, the fathers and uncles of the groom and bride shake their hands as a sign of relatedness of two families from that time. The origin of this tradition is believed to be Jewish.

During the marriage rite the father of the bride transmits to her a part of his property. A burning lamp is put on the floor, prayers are raised before transmitting this part of property in the presence of the witnesses. The burning lamp is a symbol of God's presence and the presence of the witnesses makes the whole ceremony serious. Then the ceremony and reception begin.

The most important dish is pachchoor containing rice cooked in milk and jaggery. Jaggery is also used to prepare nullikkoda. After serving rice on plantain leaves, various carry items are served always containing meat, vegetables, rice and spices in the Indian style. The first item is erissery followed by ghee. Then meat curry is served, followed by roasted meat. Fish is served after the vegetable curry, followed by leavened curd (pulissery). The next item is thoran and loose curd. The dessert is a mixture of plantain fruits, sugar and curd.

There are two other ceremonies associated with marriage: mylanchy ideel in the bride's house and chantham charthal in the bridegroom's house. Mylanchy ideel is anointing the bride's feet, hands and nose with henna, which improves the bride's beauty but also symbolizes the sins of Adam and Eve. Chantham charthal is a more complex ceremony. At first the bridegroom's face is shaved which is a symbol of his entrance into adulthood. Then he is to sit on a raised piece of wood (korandi) or on a stool covered with white cloth. The groom is also dressed in white. Then the elders of the groom's family come forward and perform nullikkoda. Now even children participate in this ceremony, which is regarded as diluting the sanctity of the function. During these ceremonies 
traditional songs are performed commemorating the arrival of the Knanites and their traditions. ${ }^{20}$

Mylanchy ideel, maduramvaikal (feeding the bride and the groom with sweets) and other customs are mostly of the Brahmin origin. The Indian customs manthrakodi kodukkal ${ }^{21}$ and thalikettu are the important elements of the marriage ceremony in the church. After the death of the woman thali is buried with her or stored in the church vault.

Then manthrakodi is placed on the bride's head by the groom. It is a sign of responsibility and protection of the newly betrothed by her husband.

There is also the custom of the goldsmith performed on the day before the marriage. He comes with minnu. He brings a plate in which there is $1 \frac{1}{4}$ measure of rice and a betel leaf on which the minnu is placed. The groom's sister receives it from the goldsmith. ${ }^{22}$ There are several types of minnu among the Knanites. One of them is a formation the shape of a cross consisting of 21 gold globules. Seven long threads taken from manthrakodi represent the idea of the Seven Sacraments. The custom is believed to be part of Jewish practices. After all the ceremonies related to the wedding manthrakodi is kept by the bride's relatives until her death. For the second time she is dressed in it after her death.

The bride's mother, uncle and grandmother hug the marriage couple and bless them. Then the groom's family gives kacha -20 yards (ca. $18 \mathrm{~m}$ ) of long cloth - to the bride's people.

The Knanaya wedding songs do not only concern marriage but they also contain the essence of many of events described in the Old Testament. The day before the marriage ceremony during chantham charthal and after it the newlyweds are asked to take their places at manarkolam (special podium). Then the women standing in two groups on both sides sing wedding songs. The first book about these songs was written by P. C. Lukas, published in 1910 with the title Suriyanichristianikalude Purathanapattukal. ${ }^{23}$ The songs are sung by men or women. The men's songs usually have some rhythm and the women's ones are without any rhythm. The songs are mostly about St Thomas and his missionary work in India.

${ }^{20}$ Joseph Kulathramannil, Cultural Heritage..., p. 3.

${ }^{21}$ Tying marital tie, thali, on the bride's neck by the groom using material and threads from manthrakodi. The Knanites hang on thali a little gold cross pendant with 7 or 21 globules of gold (symbol of the Seven Sacraments and the Holy Trinity multiplied by the Seven Sacraments).

${ }^{22}$ Joseph Kulathramannil, Cultural Heritage..., p. 4.

${ }^{23}$ Joseph Kulathramannil, Cultural Heritage ..., p. 5. 


\section{Some remarks on the Knanaya birth, burial and architecture}

Shortly after the birth the newborn's father mixes a small amount of crushed gold with honey or ghee putting it on the child's tongue and then he whispers into his ear Maran Iśo Mśiha. ${ }^{24}$

Another custom is binding pieces of black cloth on the child's wrists. The ceremony is named irupathettukettu and is celebrated on the $28^{\text {th }}$ day after the birth. In the $11^{\text {th }}$ month after the birth, in turn, the baby is fed with boiled rice (choroonu), and when he starts learning (3-5 years of age) he writes the first letter of the Malayalam alphabet - $B$ (a) (a) - with his fingers in raw rice. The custom is named ezhuthiniruthu. The woman after the birth of her child goes to church only after 40 days. There is another ceremony associated with it, called pallikayattal. On the $40^{\text {th }}$ day after the birth the child's baptism and confirmation take place and in Kerala coconut oil used for this sacrament.

The dead are buried eastwards. Mourners recite prayers and whisper to the ears of the deceased Iśo Mariam Yauseppe. ${ }^{25}$ The body of the deceased is washed and anointed shortly after death. Close relatives dress the dead in kacha as a sign of the end of their earthly relationships with the deceased. Until the funeral there is no boiling and eating in the deceased's home. Pattinikanji, cooked rice in water, is served in the deceased's home after the funeral. There is a ritual bath of all the relatives of the deceased (pulakuli) 11 days after the funeral, as a sign of removing defilement by contact with his body. Among the prayers said by priests there are manthra performed several times after the death, sradham (śraddha) and chatham that take place on the anniversaries of the death. Then offerings are collected for prayers and Qurbana for the deceased.

Before the arrival of the Portuguese the architecture of the Knanaya churches resembled the severe interior of the Assyrian churches, but on the other hand, inside or around them there were some elements of Hindu temples such as kodimaram (flag staff), peacocks and lotuses. ${ }^{26}$

St Thomas' Cross is established on the plan of lotus, growing out of the lotus, symbolizing a new life-giving tree. A dove descending on the cross symbolizes the life-giving Spirit by which Jesus was raised from the dead.

\section{Summary}

The Knanaya customs, compared to other St Thomas Christians, are characterized by considerable colour and they draw from various traditions: Jewish,

\footnotetext{
24 The words mean in Syriac "Our Lord Jesus Christ."

${ }^{25}$ In Syriac: "Jesus, Mary, Joseph."

${ }^{26}$ Joseph Thadathil, "The Indian Inheritance in the Syrian Church of India," The Harp, vol. XXI, SEERI, Kottayam 2006, p. 65.
} 
Syriac and Indian. Semitic in prayer, Indian in culture and Christian in their faith the Knanites scattered all over the world are undoubtedly an important element of the culture of India, representing religion that put down roots in this country earlier than in many parts of Europe. 
